\title{
Cooperative Integrated Reading Composition to improve pupils' reading comprehension achievement and motivation
}

\author{
Maulida Hayatina, Salina Ahdia Fajrina* \\ Institut Agama Islam Darussalam Martapura, Indonesia
}

Received: 5 Febuary 2018; Accepted: 1 September 2018; Published: 1 December 2018

\begin{abstract}
The focus of the study was to determine the effect of Cooperative Integrated Reading Composition (CIRC) to improve pupils' reading comprehension achievement and motivation. A quantitative approach with a quasi-experimental design was used for this study. Interviews were also used to support the quantitative data. A total of 54 fifth grade pupils from the district of Kalimantan, Banjar, Indonesia were involved in the study. There were 28 pupils in the experimental group and 26 pupils in the control group. Quantitative data were collected from the pre and posttests and surveys, while the qualitative data came from the interviews. The quantitative data were analyzed by using descriptive and inferential analyses. Descriptive analysis showed the frequencies, means, and standard deviation, while the inferential statistics involved an independent t-test. The findings of the pre and posttests showed that there was a significant improvement in achievement for the experimental group $(M=91.96, S D=5.33)$ when compared to the control group $(M=85.38$, $S D=5.28), t(52)=4.55, p<0.05$. The result also showed that the level of motivation for the experimental group $(M=59.96, S D=6.40)$ was significantly higher than the control group $(M=35.92, S D=6.29), t(52)=12.16, p<0.05$. Interview data indicated that pupils enjoyed reading when the teacher used CIRC in the classroom. This study showed that the use of CIRC could enhance the pupils' reading comprehension in Bahasa Indonesia. In addition, CIRC had a positive impact on the pupils' reading comprehension of Bahasa Indonesia in terms of achievement and motivation.
\end{abstract}

Keywords: CIRC, reading comprehension achievement, motivation.

\section{Introduction}

Based on the Article 1 No.24 the Education and Culture Ministry Indonesia stated that the learning processes in the primary and Islamic primary school are to be conducted through the integrated thematic approach (Tematik Terpadu). The Integrated Thematic approach is the approach which combines other subjects in one theme or topic. The reason for implementing thematic learning, as suggested by Min, Rashid and Nazri (2012), is that pupils will learn better because learning activities are initiated by problems that have been presented under selected themes. The teacher will combine multiple lessons into a single theme. For example, the teacher provides a theme of the lesson and integrates the theme with other subjects such as science and religion.

A thematic curriculum is a set of organized learning experiences that provide pupils with the opportunity to explore widely the main learning theme (Finch, Frantz, Mooney and Aneke, 1997). Min, Rashid and Nazri (2012) and Chen (2012) state that thematic learning has been one of the effective strategies for contextual learning that is related to pupils' daily experiences. In addition, teachers can support pupils in creating a connection among multiple problem solving methods. For example, in thematic learning, a teacher will design learning curricula, learning methods, and assessments and also associate materials with multiple domains of science within one theme. It emphasizes not only the multiple domains of science but also the multiple cognitive capacities such

\footnotetext{
*Email: salinaahdia@gmail.com
} 
as reading, mathematics, science, writing and society (John, 2015; Finch, Frantz, Mooney \& Aneke, 1997).In addition, thematic integrative learning in primary schools in Indonesia have been implemented together with the eighteen character values that has been compiled by the Ministry of education in the national action plan for the years beginning 2010. The eighteen character value comes from religion, pancasila, culture, and national education goals, namely: Religion, honesty, tolerance, discipline, hardworking, creative, independent, democratic, curiosity, the spirit of nationalism, patriotism, respect for the achievements, communicative, peace-loving, reading, caring for the environment, social care, and responsibility (Ministry of Education, 2010). However, according to Sadri (2012), it was found that pupils still tended to be disinterested in the learning. This was more prominent in the learning of Bahasa Indonesia where there were four important components such as reading, listening, speaking and writing.

Bahasa Indonesia is the National and instructional language in teaching and learning in the classrooms. Therefore, Bahasa Indonesia is a compulsory subject in every level of education. The pupils must learn the subject from pre-school to secondary school. Badan Standar Nasional Pendidikan (BNSP) (National Education Standards Agency) declares that the goal of learning Bahasa Indonesia is to facilitate the learners to learn and improve their Indonesian language proficiency in spoken and written forms for communication and appreciate some cultural features inherent to the language use (BSNP, 2015). Article 33 of the 2003 Education system law specifies that Bahasa Indonesia as the language of the nation shall be the medium of instruction in the national education if needed in the delivery of particular knowledge and/or skills. The pupils who learn Bahasa Indonesia must acquire the four skills which are included in learning language. From the four components, reading, writing, speaking, and listening in learning Bahasa Indonesia, reading is given prominent because reading is a very important activity in which teachers and pupils have to deal with in daily academic life.

However, reading is given priority because Grabe and Stoller (2013) stated that there are many benefits to read more often, it will improve pupils' understanding and comprehending of themselves and other people, it also introduces new information and idea. Furthermore, reading will improve pupils' vocabulary and increases their reading speed. It shows that reading is one of important skills that must be mastered (Grabe \& Stoller, 2013).

According to Richardson, Morgan and Fleener (2012), the primary goal of reading is to comprehend who, what, when and where of the story. In fact, there are many pupils who have difficulties in reading especially in comprehending or understanding the content of the text. Based on a research that was conducted by the Programme for International Pupil Assessment (PISA) in 2015 , the reading ability of Indonesian pupils was in the in $69^{\text {th }}$ position out of 76 countries. It showed that Indonesian pupils have low comprehension in reading (Abbas, 2017).

Although Bahasa Indonesia has been the main language in the level of education, it appears that they are not overly concerned about whether they can read well or not. According to the International Organization Concerning Indonesian Elementary School Pupils (IESS), it states that the reading comprehension abilities of the Indonesia pupils need to be considered (PISA report, 2015). The PISA reported the findings from IESS and found that the average score of reading comprehension among Indonesian pupils are low and it fell below the Organization for Economic Co-operation and Development (OECD) countries' average. The low score from IESS reading comprehension ability could have been influenced by their poor understanding of the main idea of a paragraph, poor reading, relationships between facts, and relationships of linguistic understanding. Another international organization featured similar daunting report.

Other issues identified are the pupils' reading interest and motivation (Maulidi, et.al, 2014). Interest has an important role as it will influence other factors of reading problems, such as motivation (Unsworth \& Micmillan, 2013). As Guthrie and Cambria (2010, p.16) define motivation as "when we think of motivation our mind first turns to interest. Motivation is enjoying a book, being excited about an author, or being delighted by new information. So, if the motivation is important for interest, then if the pupils do not have interest, it is possible for them to be demotivated to read (Unsworth \& Micmilan, 2013).

Pupils assume that reading is a boring activity since they have to read long paragraph from the written text then answer the questions based on the text (Maulidi et al., 2014). When they are not 
familiar with the words in the content in the long paragraph they will ignore the questions and tend to do 'gamble' in choosing the answers from multiple choice tests. Considering the importance of interest and motivation, Maulidi et al. (2014) believes that the quality of language teaching and learning practices in the classroom is one of the important factors to pupils learning process, especially in reading comprehension.

Regarding to the problem indicated, there is a need for the improvement in teaching reading skills towards comprehension in the classroom in order to achieve the goals of learning that has been determined by the Ministry of Education in Indonesia. Towards this end, the researcher has undertaken a quasi experimental by implementing one of cooperative learning technique namely cooperative integrated reading composition (CIRC) technique in the reading class. The reason is that in CIRC technique, the pupils are able to cooperate and interact with one another in a group.

Based on the issue of how reading comprehension, motivation and interest, Astuti (2016) suggested that cooperative integrated reading composition (CIRC) technique might provide a structure to help teachers and pupils succeed in helping all pupils become effective reader. This technique has potential to be used during practice which is expected to enable pupils to practice and promote their reading comprehension. In addition, Rahmawati, Padmadewi and Ratminingsih (2014) state that one of the characteristics of this technique is that it might give maximum opportunities for meaningful output and input in highly interactive environment which can create interest and motivation. It happens because the pupils have a chance to work together with their friends in a group. The teacher plays as a facilitator during reading practice activities in the classroom. Further, it is possible to give meaningful input through these activities during the teaching and learning process.

\section{Research Questions}

i. Was there any significant difference using cooperative integrated reading composition (CIRC) and conventional (integrated thematic approach) teaching method in improving pupils' reading comprehension?

ii. Was there any significant difference using cooperative integrated reading composition (CIRC) and conventional (integrated thematic approach) teaching method in improving pupils' motivation towards reading?

\section{Literature Review}

According to Adams (2013) and Slavin (1995), cooperative learning is an instructional technique which is arranged systematically. To accomplish the goal, small group works together. Cooperative learning utilizes various characteristics and strategies in the classroom. For instance, positive interdependence, face-to-face interaction, individual accountability, social skills, and group processing are concerned to pertain at cooperative learning.

Cooperative learning (formerly called pupils-team learning) is the term used to describe interactional procedures whereby learners work together in small groups and are rewarded for their collective accomplishments (Cruickshank, Jenkins, Metcalf, 2012). Cooperative learning in many other ways of teaching, encourages the pupils to work together which then cultivate motivation and interest and also provide the improvement of higher achievement (Cruickshank et al., 2012)

There are many cooperative learning methods based on Slavin (1995), such as Jigsaw, Pupil team-achievement Division (STAD), Teams Games Tournament (TGT) and Group investigating. However, this study situates itself on the use of the Cooperative Integrated Reading Composition (CIRC) method. Cooperative Integrated Reading and Composition (CIRC) is used specifically for language learning. According to Manisah Manshor and Zawawi Zainal (2013) the main principle for the use of CIRC are reading, understanding, and writing. According to Yudasmini (2014) cooperative learning such as CIRC is a comprehensive program that is used to teach reading and writing for the upper primary school education. 
Cooperative integrated reading composition (CIRC) is mainly used to teach reading and composition. In the typically CIRC procedure, the teacher sets lesson in some specific area of reading or composition. The pupils are asked to work in pairs or in groups. To emphasize the individual competency, the teacher use quizzes which are taken individually. To use CIRC, the pupils should involve in group work and work cooperatively. Institute of education and sciences (2012) reports that CIRC has three principal elements: story-related activities, direct instruction in reading comprehension, and integrated language arts/writing. Daily lessons provide pupils with an opportunity to practice comprehension and reading skills in pairs and small groups. Pairs of pupils read to each other; predict how stories will end; summarize stories; write responses to questions posed by the teacher; and practice spelling, decoding, and vocabulary. Within cooperative teams of four, pupils work to understand the main idea of a story and work through the reading activities linked to the story.

In addition, CIRC technique provides pupils the opportunity to plan, revise and summarize their story in a collaborative team (Desy, 2017). In CIRC, groups of heterogeneously grouped pupils co-operate with each other to read, to find main idea, and give opinions to text and at the end, the pupils write the result on the paper. They make presentation or read the result from group's discussion and make summary of this work together. They have equal opportunities for success. CIRC provides a structure for the teacher to teach and pupils to learn which will help all pupils become more effective readers.

Reading comprehension is the process of constructing meaning involving the written language by interpreting textual information in the light of prior knowledge and experiences using appropriate and efficient comprehension strategies (Just, 2013). Comprehension is the goal of reading. When someone began to read there is a number of initial decisions to make, usually some people make decisions very quickly, almost unconsciously in most cases. According to Sanford (2015) reading helps pupils to foster comprehension because as pupils read longer passages, they unite what they have read over the course of the text. This ability requires pupils to synthesize information, decode and define words, and integrate what they are reading into what they already know. Comprehension is also affected when pupils do not have a rich vocabulary because they are unable to apply word knowledge to the current context.

In reading comprehension, the process of constructing meaning is the process in which the reader uses their prior knowledge with additional information about the topic, language, structure, and text structure to understand the meaning (Just, 2013). Then, for understanding the message, the reader also needs to use various strategies such as predicting, clarifying, and confirming. From the definition above, reading comprehension can be defined as the process in which the readers construct meaning from a text connected to the background knowledge they have to get the clear understanding of the writer's message.

According to Cherry (2012), motivation is defined as the method that allows people to initiate, engage, and persist in an activity which is based on an objective. Motivation to read is an intrinsic desire to read for various reasons; attention, participation, social interaction, and many others (Gambrell, 2011).

Motivation is the key to be successful readers. It also affects how pupils come up to school in general, how they communicate to teachers, how much time and effort they offer to their studies, how much support they look for when they are struggling, how they perform on tests, and many other aspects of education. If pupils are not motivated, it is difficult to improve their academic achievement, no matter how good the teacher, curriculum or school is (Moomaw, 2013). Motivation is a factor of whether we choose to do, or not do to certain activities. This means that the more motivated a pupil is, the more reading the pupil will do (Moomaw, 2013).

\section{Methodology}

The research used a quasi experimental design. The main objective of the quasi experimental design is to ensure that the changes occurring on the dependent variable are due to the independent variable. 
This was a quantitative research with aspects of qualitative data (through interview) to support and complement the quantitative results. The participants in this research were fifth grade pupils who were ten years old studying in the primary school in school A.

The population of fifth grade pupils in school A comprised three classes with a total of 84 pupils. In these three classes, there were 41 males and 43 females. School A did not place pupils according to their achievement scores; instead pupils have been placed according to the date they registered for entry into the school in Grade 1.

The researcher placed all three classes (Class A, Class B and Class C) in a box and the first class selected from the box was made the experimental group and the second class selected was made the control group. Class $\mathrm{C}$ was the experimental group and Class $\mathrm{B}$ was the control group (Table 1).

Table 1. The demographic of research participants

\begin{tabular}{lllll}
\hline Group & Class & Enrolment of pupils & Sex & \\
\hline & & & Male & Female \\
Experimental & C & 28 & 15 & 13 \\
Control & B & 26 & 13 & 13 \\
Total & & & 25 & 35 \\
\hline
\end{tabular}

A total of 54 fifth grade pupils were involved in the study. There were 28 pupils in the experimental group and 26 pupils in the control group. Two teachers also were involved in this study from School A. Teacher A taught the experimental group while teacher B taught the control group. Both the teachers were female. They were similarly trained and are qualified with the Bachelor Degree of Teaching in Indonesia.

\section{Results and Discussion}

\section{Posttest Results between the Experimental and The Control Groups (Research Question 1 and Hypothesis 1)}

In order to find out if reading during practice using CIRC made any significant differences during the six weeks of intervention, the posttest scores were collected from both the experimental and the control groups. This section answered the first hypothesis that was to see if pupils in the experimental group using CIRC during practice would perform better than those in the control group using the conventional practice (integrated thematic approach) on the reading achievement tests.

Table 2. Posttest results between the experimental and the control groups

\begin{tabular}{lllllll}
\hline Groups & Mean & $\begin{array}{l}\text { Std. } \\
\text { Deviation }\end{array}$ & $\begin{array}{l}\text { Mean } \\
\text { Difference }\end{array}$ & $T$ & Df & Sig. (2-tailed) \\
\hline $\begin{array}{l}\text { Experimental } \\
\text { N=28 }\end{array}$ & 91.96 & 5.33 & 6.58 & 4.55 & 52 & .00 \\
$\begin{array}{l}\text { Control } \\
\mathrm{N}=26\end{array}$ & 85.38 & 5.28 & 6.58 & & & \\
\hline
\end{tabular}

Note: $\mathrm{p}<0.05, \mathrm{~N}=52$

Table 4.4 shows the results of the t-test analysis on the post-tests between the experimental and control groups. The results showed that the mean score for the experimental group was $\mathrm{M}=91.96$ and the mean score for the control group was $\mathrm{M}=85.38$ indicating that there was a significant difference between the two groups, $\mathrm{t}(52)=4.55, \mathrm{p}=.00, \mathrm{p}<.05$ This implied that the experimental group performed significantly better than the control group. Consequently, this finding accepted the hypothesis that there was a significant difference in pupils' reading achievement using cooperative integrated reading composition (CIRC) during practice. 
The mean results of the quantitative data (pretest, posttest) showed that the experimental group performed better than the control group after the use of CIRC during practice. Based on the analysis on the post tests conducted, the results obtained were that there was a significant difference in the scores for experimental group $(M=91.96, S D=5.33)$ and control group $(M=85.38, S D=5.28)$ $(t=4.55, p=.00)$. It showed that CIRC used in this study had a statistically positive influence on the reading comprehension achievement of the experimental group compared to the conventional integrated thematic approach. The findings of the research is similar to the findings of a previous research by Metaleli (2014) who investigated the pupils' ability in reading comprehension on narrative text, he found that after applying CIRC in teaching learning activities, pupils showed improvement in reading, such as content, organization of words, vocabulary, grammar, and the mechanics of reading and writing. Through supportive and a collaborative learning environment instituted by CIRC, pupils were stimulated and were instilled towards completing the tasks. Overall, the result of this study showed that the use of CIRC techniques during practice can improve pupils' reading comprehension achievement when compared to integrated thematic approach. According to Yudasmini (2014), the improvement in the reading comprehension achievement occurred as a result of the activities that were conducted cooperatively. This is because not only the activities were done collaboratively but also the teacher guided them in the learning process, such as as pair-work, discussion about a story, pronouncing the difficult words, finding the word meanings, and making inference from reading the text which are CIRC part of the attribute of CIRC which helped improved reading. In addition, the Institute of Education and Sciences (2012) reported that pairs works, predicting how stories will end, writing responses to questions posed by the teacher in the use of CIRC helped pupils to understand the main idea of a story and work through the reading activities linked to the story.

\section{T-Test Analysis of Motivation for Experimental and Control Group (Research Question 2 and Hypothesis 2)}

The data presented in this section was obtained using the Motivation for Reading Questionnaire (MRQ). The questionnaire was conducted to investigate the second research question of this study; Is there any significant different using cooperative integrated reading composition (CIRC) and conventional teaching method (integrated thematic approach) in improving pupils' motivation towards reading?

Table 4. An analysis of T-test for motivation

\begin{tabular}{|c|c|c|c|c|c|c|c|}
\hline \multirow{3}{*}{ Pre and post tests } & \multicolumn{7}{|c|}{ Motivation } \\
\hline & \multicolumn{2}{|c|}{$\begin{array}{l}\text { Experimental group } \\
(n=28)\end{array}$} & \multicolumn{2}{|c|}{$\begin{array}{c}\text { Control group } \\
(n=26)\end{array}$} & \multirow[t]{2}{*}{$D f$} & \multirow[t]{2}{*}{$t$} & \multirow[t]{2}{*}{$\begin{array}{l}\text { Sig. (2- } \\
\text { tailed) }\end{array}$} \\
\hline & $\mathrm{M}$ & SD & $\mathrm{M}$ & SD & & & \\
\hline Pre & 46.00 & 5.57 & 45.58 & 4.18 & 52 & .31 & .75 \\
\hline Post & 56.96 & 6.40 & 35.92 & 6.29 & 52 & 12.16 & .00 \\
\hline
\end{tabular}

Table 4 showed that the pretest score for the motivation in reading Bahasa Indonesia between the experimental group $(M=46.00, S D=5.57)$ and the control group $(M=45.58, S D=4.18)$ was not statistically significant, $t(52)=.31, p=.75$. However, after the intervention, a significant difference was found between the experimental group $(M=59.96, S D=6.40)$ and the control group $(M=35.92, S D=6.29)$ in the post test, $t(52)=12.16, p=.00$. Figure 4.2 showed the change of the motivation in reading Bahasa Indonesia in both groups. However, there was a decrease in the mean value of the control group even though there was not intervention. Probably, the teacher or the Education Ministry would need to relook at the reason why integrated thematic curriculum might not be able to motivate the pupils.

The result from the pupils' questionnaire on motivation showed a statistically improvement in the experimental group of pupils $(M=56.96, S D=6.40)$ and compared to the control group $(M=35.92, S D=6.29),(t=12.16, p=.00)$. This result confirmed the research hypothesis that the use of 
CIRC was able to improve the pupils' motivation towards reading. This finding is consistent with research results obtained by Manisah Manshor and Zawawi Zainal (2013) who mentioned that when CIRC was used, pupils were asked to work in pairs and discuss about a topic that the teacher gave. The teacher gave the opportunity to the pupils to comprehend and show their ideas. The pupils then elaborate their knowledge and shared to each other. By using CIRC, the pupils paid more attention and showed greater enthusiasm when reading. They were more active and attentive in group work. According to Gambrell (2011), when pupils used CIRC, the motivation to read was an intrinsic desire to read for various reasons; attention, participating, and social interaction.

However, from the interview, one of the pupils also stated that "I don't know the main idea in the paragraph, I am lazy to read if there are many long paragraphs." This found that those who felt inhibited when starting reading, will find it very difficult to comprehend a paragraph of main ideas from the text. According to Johnson and Johnson (2017) certain pupils would have problems in reading because they were bored. They would feel reading was difficult and they did not know the way to read effectively and enjoyably. Therefore, the teaching strategies in the classroom will influence pupils' reading motivation. The activities in the teaching process would also stimulate the pupils to like reading. Melekoglu and Wilkerson (2013) found that the motivation was the influence on the choice of learning strategies through CIRC motivated learners.

Overall, the feedbacks from the pupils were encouraging. In supporting the questionnaire results, the focus groups interview findings showed that the pupils were motivated and interested in reading Bahasa Indonesia taught by CIRC. Pupils of experimental group gave responses about their perceptions and preference in reading Bahasa Indonesia. Teacher A was also being interviewed to give her views in using CIRC during the teaching practices in her classroom. The teacher was giving her perceptions and thoughts about teaching using CIRC in relation to the pupils' reading achievement, motivation and interest.

\section{Conclusion}

This study finds that the subjects in the experimental group were positive in learning using CIRC. The subjects enjoyed the techniques and commented how they helped towards reading in Bahasa Indonesia. Moreover, the analysis of the posttest scores between the experimental group and control group showed that there was a significant difference. Analysis of the pupils' responses to the questionnaires seem to indicate that the majority of the pupils showed good motivation. The analysis of the interview data showed that the pupils' preferred CIRC techniques as it assisted them in reading. Among the reasons cited were that they work in groups and got support from their peers. The interview revealed that CIRC techniques enabled them to improve their reading achievement, motivation and interest. Furthermore, the use of CIRC technique during practice encouraged social interaction which preceded learning, as they were exposed to work in groups.

As learners are often faced with an intimidating feeling throughout their academic life, knowledge of techniques and teaching strategy could help teachers improve their teaching reading in Bahasa Indonesia. The teachers could play their roles in improving their strategies to encourage and engage the pupils to become more aware in reading. As a conclusion, CIRC should be used and made an integral part of any reading lessons in the classroom as it can help to enhance the confidence of the pupils in reading and offer then a chance to become better in comprehending Bahasa Indonesia.

This study finds that the subjects in the experimental group were positive in learning using CIRC. The subjects enjoyed the techniques and commented how they helped towards reading in Bahasa Indonesia. Moreover, the analysis of the posttest scores between the experimental group and control group showed that there was a significant difference. Analysis of the pupils' responses to the questionnaires seem to indicate that the majority of the pupils showed good motivation. The analysis of the interview data showed that the pupils' preferred CIRC techniques as it assisted them in reading. Among the reasons cited were that they work in groups and got support from their peers. The interview revealed that CIRC techniques enabled them to improve their reading achievement, 
motivation and interest. Furthermore, the use of CIRC technique during practice encouraged social interaction which preceded learning, as they were exposed to work in groups.

As learners are often faced with an intimidating feeling throughout their academic life, knowledge of techniques and teaching strategy could help teachers improve their teaching reading in Bahasa Indonesia. The teachers could play their roles in improving their strategies to encourage and engage the pupils to become more aware in reading. As a conclusion, CIRC should be used and made an integral part of any reading lessons in the classroom as it can help to enhance the confidence of the pupils in reading and offer then a chance to become better in comprehending Bahasa Indonesia.

\section{References}

Abbas, A. (2017). Designing big story book project (BSBP) in teaching reading comprehension. Ethical Lingua. Journal of Language Teaching and Literature, 4(1), 61-67.

Adams, F. H. (2013). Using jigsaw technique as an effective way of promoting co-operative learning among primary six pupils in Fijai. International Journal of Education and Practice, 1(6), 64-74.

Asian Development Bank. (2015). Education in Indonesia: Raising to the Challenge. Paris: OECD Publishing.

Astuti, D. S. (2016). The effectiveness of cooperative integrated reading and composition (CIRC) method in teaching reading skill viewed from pupils' interest. Jurnal Pendidikan Bahasa, 3(1), 73-88.

Cambria \& Guthrie. (2010). Motivating and engaging pupils in reading. The NERA Journal. 46(1), 16-29.

Chen, Y.T. (2012). The effect of thematic video-based instruction on learning and motivation in e-learning. International Journal of Physical Sciences. 7(6), 957-965.

Cherry, K. (2012). Theories of motivation. A closer look at some important theories. New York USA: Wadsworth Publishing.

Cruickshank, D. R., Bainer, D.L., \& Metcalf, K. K. (2012). The act of teaching (6 $6^{\text {th }}$ ed.). New York: McGrawHill Collage.

Finch, C. R., Frantz, N. R., Mooney, M., \& Aneke, N. O. (1997). Designing the thematic curriculum: an all aspects approach. Barkeley, CA: National Center for Research in Vocational Education Graduate School of Education University of California.

Gambrell, L. B. (2011). Seven rules of engagement: What's most important to know about motivation to read. The Reading Teacher Journal, 65(3), 172-178.

Grabe, W. P., \& Stoller, F. L. (2013). Teaching and researching: Reading. Newyork: Routledge.

John, Y. J. (2015). A" New" thematic, integrated curriculum for primary schools of Trinidad and Tobago: A Paradigm Shift. International Journal of Higher Education, 4(3), 172-187.

Just, M. A. (2013). Cognitive processes in comprehension. New York: Psychology Press.

Manisah, M., \& Tengku, Z. Z. (2013). Kesan pembelajaran kooperatif ke atas pencepaian Matematik dan pengekalan pengetahuan dalam kalangan pelajar tingkatan dua. MUADDIB Research Journal, 7(1), $1-12$.

Maulidi, A. D. R., Sutarsyah, C., \& Suparman, U. (2014). An analysis of pupils' problems in finding main idea of reading text. $U-J E T, 7(3)$. 1-8.

Melekoglu, M. A., \& Wilkerson, K. L. (2013). Motivation to read: How does it change for struggling readers with and without disabilities? International Journal of Instruction, 6(1), 77-88.

Min, K. C., Rashid, A. M., \& Nazri, M. I. (2012). Teachers' understanding and practice towards thematic approach in teaching integrated living skills (ILS) in Malaysia. International Journal of Humanities and Social Science. 23(2), 273-281.

Moomaw, J. (2013). Factors That Foster or Hinder Student Reading Motivation in a Suburban Primary School (master's thesis). Retrieved from http://digitalcommons.brockport.edu/ehd_theses/198.

OECD/Asian Development Bank (2015), Education in Indonesia: Rising to the Challenge, OECD Publishing, Paris. Retrieved October 12, 2017 from http://dx.doi.org/10.1787/9789264230750-en.

Rahmawati, L., Padmadewi, N. N., \& Ratminingsih, N. M. (2014). The effect of circ strategy and achievement motivation toward pupils/'reading comprehension. Language Education Journal, 3(1), 1-13.

Richardson, J. S., Morgan, R. F., \& Fleener, C. (2012). Reading to learn in the content areas. Boston: Cengage Learning.

Sadri, N. W. (2012). Studi evaluasi implementasi pembelajaran matematik pada sekolah dasar gugus I Denpasar Timur di Denpasar. Jurnal Penelitian dan Evaluasi pendidikan Indonesia, 2(1), 1-12. 
Sanford, K. L. (2015). Factors affecting the reading comprehension of secondary students with disabilities. American Journal of Education Research, 5(5), 574-578. doi: 10.12691/education-5-5-16.

Unsworth, N., \& McMillan, B. D. (2013). Mind wandering and reading comprehension: examining the roles of working memory capacity, interest, motivation, and topic experience. Journal of Experimental Psychology: Learning, Memory, and Cognition, 39(3), 832.

Yudasmini., Marhaeni., \& Jampel. (2015). The influence of CIRC to improve reading comprehension and interest at sixth grade Gugus Buruan primary school. Ganesha Education University Journal, 5(1), 19. 